\title{
Is the implementation of self-assessment effective in improving the Iranian EFL students' writing?
}

\author{
Farzaneh Rahmanpour \\ Department of English Language and Literature Larestan Branch, \\ Islamic Azad University, Larestan, Iran \\ E-mail: farzane.rahmanpour@yahoo.com \\ Abusaied Janfaza \\ Department of English Language, Javid University, Jiroft, Iran \\ E-mail:s_janfaza@hotmail.com \\ Afshin Soori \\ Department of English Language and Literature Larestan Branch, \\ Islamic Azad University, Larestan, Iran \\ E-mail: afshin_soori@yahoo.com
}

\begin{abstract}
Writing skill is an important skill which is a requirement for the future success of a learner, and providing feedback by teachers on the students' writing a challenging issue. Self-assessment is almost a new trend in writing instruction. This study tries to investigate the effectiveness of the implementation of self-assessment in a writing classroom. To this end, 46 Iranian university students in Islamic Azad University, Kerman, Iran served as the participants of this study. The students were studying in English field of study. They were in a range of 20 to 24 who had taken the writing course voluntarily. In terms of the result of the proficiency test, the students were assigned randomly into two groups (an experimental and a control group). The students in the experimental group used self-assessment method and the students in the control group used the teacher assessment (traditional method) in the classroom. The findings of the current study revealed that the implementation of the self-assessment was helpful in the writing classroom and improved the overall abilities of the Iranian students.
\end{abstract}

Keywords: Self-assessment; writing skills; EFL students.

\section{Council for Innovative Research}

Peer Review Research Publishing System

\section{Journal: Journal of Advances in Linguistics}

\author{
Vol 4, No. 3 \\ editor@cirjal.com \\ www.cirjal.com
}




\section{Introduction}

Today, the implementation of multi-media technologies to improve innovative modes of language learning is the final aim of educational institutions. In this case, distance and independent learning are good solutions which provide opportunities for whom not be able to participate in regular language classrooms (Nielsen, 2014). In distance learning, the physical participation of learners are not necessary, however, they are in contact with teachers or instructors. In contrast, in independent learning, a learner is not in contact with the teacher, but s/he independently studies, and he doesn't receive any support or aid from a teacher or other learners.

Assessment in distance education is similar to the assessment in classroom-based learning. In both of them learners may self-mark some exercises, and these learners may receive some peer-feedback on their errors. However, in a regular classroom, a student refers to the course teacher to assess his or her paper (Diltz 2006).A problematic issue in independent learning programs, "whether stand-alone courses or self-access supplements to class teaching" is assessment (Meihami \&, Varmaghani, 2013, p.40). In fact, when there is no teacher or other students, the burden is on the students themselves, and they should monitor their errors and assess their progress.

Two traditional methods of self-assessment of language ability are as follows "(i) objectively-marked discrete-point tests of linguistic knowledge, and (ii) rating scales or checklists" (Brindley \& Scoffield, 1998; Oscarson, 1989, as cited in Meihami \&, Varmaghani, 2013, p.40). Objective tests can be considered as reliable self-assessment instruments. However, these types of tests do not let students have opportunities to produce a complex oral or written performance. They let students to identify where they have some problems in linguistic knowledge, but does not let them assess their ability "to put their newly-acquired linguistic resources to use in sustained productive performance" (Meiham i\&, Varmaghani, 2013, p.40).

Nielson (2014) believes that rating scales or checklists are based on situational descriptions, but they do not need any immediate performance. They seem relatively unreliable and they need the students to be able to make their own interpretation of standards, and have a complete experience of a particular situation (Ross, 1998). This type of selfassessment does not related to any specific courses of learning, but they can be used to assess the proficiency levels based on placement purposes (Brindley \& Scoffield, 1998).

It seems that neither of these methods of self-assessment is helpful in a range of assessment contexts, and the learners do not have an actual productive (written or spoken) performance. In spite of the potential for "fruitful development of selfevaluated language learning" that has been proposed by new technologies (Oscarson, 1989, p. 10), there is no preference for self-assessment by the learner.

Since the assessment of productive skills is "highly-subjective and complex domain," it may beyond the reach of the students (Hirvela \& Pierson, 2000, p. 113). Self-assessment of actual productive may take place "in the context of reflection on and selection of work for portfolios, which typically takes place within teacher-led courses and is guided to a large extent by a teacher" (Hirvela \& Pierson, 2000 as cited in Meihami\&, Varmaghani, 2013, p.40). In self-assessment process is more focused than outcome (Porter \& Cleland, 1995), and the focus is also on the identification of grammatical errors committed by the students in the written texts. Teachers provided the students with some marking codes which indicate the grammatical errors. Therefore, the students are able to correct their own works, but they fail to focus on content, organization, and coherence.

There is no autonomous approach to evaluate the students' text production, so, it causes some problems for communicatively-oriented independent learning programs where the main purpose is to increase the student's ability to produce effective written or spoken text. The reason for this problem as Nielsen (2014) mentions refers to the lack the presence of a teacher to give feedback on the students' written errors. Thus, students require to do the self-correction on their own accurately. In an independent learning program, the learners do not have the opportunity to receive feedback. Thus, they are less motivated (Warne 2008).

\section{Literature Review}

From the year 2000 onwards, self-assessment has been drastically used in numerous education setting all over the world. The first self-assessment was reported in the late nineties (Blanche and Merino1989). From that time on, self-assessment has been a distinct major in second language education. In self-assessment or some other self-reflective activities, students usually grade their peers or their performance which depends on the requirements of the task or the criteria taken from the students' input. The types of assessment are different from standardized questionnaires (e.g., AlFalley, 2004; Bachman \& Palmer, 1989; Patri, 2002; Stefani, 1994) to informal activities like portfolios (e.g., Cotteral, 2000; Donato \& McCormick, 1994).

The construct of self- assessment in second language acquisition can be considered as an alternative means which can assess the learners' ability. To this end, "self-assessment researchis primarily quantitative in nature and explores the validity and reliability of student self-ratings (e.g., AlFalley, 2004; Bachman \& Palmer, 1989; Blanche, 1990; Boud, 1995; Boud \& Tyree, 1995; Butler \& Lee, 2006; Pierce, Swain, \& Hart, 1993) rather than the learning process involved in selfappraisal activities"(Meihami \&, Varmaghani, 2013, p.41). Regarding this issue, some main questions are as follows: (a) Is self-assessment a reliable tool to assess performance?(b) What variables can affect the reliability of scores? And (c) how these variable are controlled? The reliability of self-assessment can be measured through correlation of self-assessed performance score with the score of the instructor or standardized tests.

There are different variables can affect self-assessment which can range from "the domain of assessment to item construction and the learners' individual attributes such as personality traits, affectivity, and level of proficiency" (Bachman \& Palmer, 1989; Blanche \& Merino, 1989; Butler \& Lee, 2006; Ross, 1998 as cited in Meihami \&, Varmaghani, 2013 , p.41 
). The results show that self-assessment procedures can't be used for summative purposes assessment because they are too subjective.

It seems that the construct of self-assessment has been changed from concerning assessment theory to consider selfassessment as a tool to motivate and increase learning. The interests for self-reflective practices have originated from motivation and autonomy in models and research (Noels, Pelletier, Cle'ment, \& Vallerand, 2000). In this case, transferring the responsibilities from teachers to students can increase motivation among the students. Thus, self-assessment can act as a means for this transferring and makes the students self-regulated. To Noels (1999), motivation, self-reflection and feedback are interrelated.

Noels et al., (2000) believed that in L2 language learning process, the students were less anxious when they werein an autonomy-supportive environment. Therefore, self-assessment is possible to make an interface between feedback, selfreflection, and autonomous learning, which enable "both learner and instructor to reflect on the learning process and to give or receive mutual feed-back" (Cotteral, 2000; 1999; Tremblay \& Gardner, 1995, as cited in Meihami \&, Varmaghani, 2013, p.42).

According to Tremblay and Gardner (1995), self-efficacy is considered as the learner's perceived ability "to meet the challenge of language learning in relation to specific tasks and suggested that anxiety is a debilitating component of selfefficacy" (p. 508). In fact, language anxiety and self-efficacy can be related to each other in an opposite direction. In this case, the anxiety should be lessened and self-efficacy should be increased.

The findings of previous research (e.g. Gardner, Tremblay, \& Masgoret, 1997; Horwitz et al., 1986; Maclntyre, Noels, \&Cle'ment, 1997), have shown that there is a negative relationship between achievement and language anxiety. Moreover, the results of some other studies (e.g., Horwitz et al., 1986; Young, 1986, 1990) have indicated that there is a relationship between speaking skills and foreign language anxiety.

To Gardner et al. (1997 as cited in Meihami \&, Varmaghani, 2013) anxiety can be related to some deficits in listening comprehension, "impaired vocabulary learning, reduced word production, and low grades in the language course" (p.42). Horwitz (2001) believed that anxiety can make language learners underestimate their abilities. To Mills, Pajares, and Herron (2007), students' self-efficacy not anxiety is related to academic performance.

In fact, teachers can help students to increase self-efficacy and decrease language learning anxiety. Tremblay and Gardner (1995)pointed out that teachers should help students to set appropriate purposes because "individuals with specific and challenging goals persist longer at a task than individuals with easy and vague goals" (p. 508). Mills et al., (2006)believed that encouraging learners should adopt some helpful strategies like planning and monitoring to increase some proactive linguistic behavior. In this case, proactive and goal-setting strategies can help learners to "attribute success or failure to their own level of effort and strategy use, rather than factors outside their control such as luck or task difficulty" (Meihami \&, Varmaghani, 2013, p.42). Therefore, this ability can help learners to increase a sense achievement (Graham, 2004)

According to Warne (2008), a well-suited tool for helping learners to increase their abilities and monitor their efforts is selfassessment. To this end, the end point of process shouldn't be self-reflective activities. So, "they are traditionally defined in self assessment research, but rather an ongoing, dynamic tool for reflecting concurrently on past and possible future performance and learning behavior"(p.248).

The socio-cultural theory considers the role of learners as active agents in their own learning. Lantolf and Thorne (2006), refer to some critical notions of agency in learning process. They explained agency "as the ability of individuals to assign relevance and significance to things and events" (p. 143). However, this ability is influenced by the learners' learning goals.

According to Ridley (2003), if the learners exercise agency, they will become autonomous learners, and self-regulated learners. Regarding this issue, Ushioda (2003) discussed that learning motivation is not just within the learners, but it is also socially distributed. In addition, the classroom can be considered as a social unit which can improve the motivation among the language learners. Ushioda (2006) also refers to the learning environment which can be supportive rather than inhibitive for language learners. Thus, their motivation and self-confidence will also increase.

Regarding the related literature, this study aims at investigating the impact of using self-assessment on improving the writing ability among the Iranian EFL students. Thus, the research questions as follows: Is using self-assessment effective in improving the Iranian EFL students' writing?

\section{Methodology}

\subsection{Participants}

A total number of 60 Iranian EFL male and female students in Islamic Azad University, Kerman, Iran were the participants of the study. The students were studying in English field of study. They were in a range of 20 to 24 who had taken the writing course voluntarily. This course was a free credit course. Prior to the treatment, the students took a proficiency test. In terms of the result of the proficiency test, 46 students who got the highest scores were selected for this study. The students were assigned randomly into two groups (an experimental and a control group) of 23 in each group. The duration of treatment was six weeks, two sessions a week. The teacher of two groups was the same. The students in the experimental group used self-assessment method and the students in the control group used the teacher assessment in the classroom. 


\section{Procedure}

In the first session, all the students took a pre-test before the program starts. In the second session, the teacher talked about the purposes and the principles of self-assessment for the students of experimental group. Afterward, the students of the experimental group received instructions on essay writing. They were taught how to remove some problems like punctuation, sentence formation, and some grammatical points. Then, the students were asked to write an essay in terms of the points they had been taught. In the next session, the students brought the writing they had written into the classroom. They did self-assessment on their writing papers. Then, the teacher provided feedback on their errors. In the last session, the students took a post-test.

Like experimental group, the students in control group took a pre-test before the start of the program. The teacher prepared some tips on how to write an English essay. Then, the students in the control group wrote their writing papers in terms of the tips they had learned. In the following session, the students came to class with their writing papers, and the teacher gave feedback on their essays in terms of the traditional assessment method. In the final session the students took the post-test.

\section{Results}

The outcomes of the current study reveal some interesting points. The descriptive statistics related to both experimental and control groups were illustrated in Table1.

Table1. Descriptive statistics of Experimental and Control groups

\begin{tabular}{llccc}
\hline \multirow{3}{*}{ Experimental Group } & Test & Mean & Std. Deviation & $\mathrm{N}$ \\
& Pre-test & 58.23 & 17.457 & 23 \\
& Post-test & 72.44 & 12.754 & 23 \\
Control Group & Pre-test & 58.97 & 16.968 & 23 \\
& Post-test & 62.75 & 11.532 & 23 \\
\hline
\end{tabular}

As shown in Table1, two groups have been compared. The mean score of experimental group is 58.23 and the mean score of the control group is 58.97. The comparison between the mean scores between two groups showed that there were no considerable differences between mean scores. Thus, it was a good confirmation that the students had the same proficiency level prior the treatment. Unlike during the pre-test, the comparison between the mean scores betweentwo groups in the post-test revealed that there were considerable differences between mean scores. In the post-test, the mean score of the control group was 62.75 which shows an improvement of 3.78 scores from the pre-test to post-test. In contrast, the mean score of the experimental group was 72.44 which indicates an improvement of 14.21 scores from the pre-test to post-test. To answer the research question, Tests of Between-Subjects Effects was run. Table 2 reveals the data analysis.

Table 2. Tests of Between-Subjects Effects

\begin{tabular}{|l|l|l|l|l|l|l|}
\hline Source variable & $\begin{array}{l}\text { Type III Sum } \\
\text { of Squares }\end{array}$ & Df & Mean Square & F & Sig. & Partial Eta Squared \\
\hline $\begin{array}{l}\text { Experimental Group } \\
\text { Test } \\
\text { Control Group }\end{array}$ & 1965.23 & 1 & 1965.23 & 8.054 & .003 & .157 \\
\cline { 2 - 7 } & 6523.54 & 1 & 6523.54 & .345 & .645 & .006 \\
\hline
\end{tabular}

The results of Tests of Between-Subjects Effects can justify the rejection of the null hypothesis. The $p=.003$ for the experimental group justifies for the rejection of null hypothesis and confirms that the implementation of self-assessment is effective in improving the writing ability among the Iranian EFL students. 


\section{Conclusion}

The findings of the current study reveal that the implementation of the self-assessment can be helpful in the writing classroom and improves the overall abilities of the Iranian students. In this case, the findings can support the results of the previous studies (e.g. Mills, et al., 2007 and Noels et al., 2000) on the implementation of the self-assessment for improving writing abilities. It was found that the students in the experimental group improved in writing and gain more knowledge in comparison to the students in the control group which didn't do any self-assessment.

As a final remark, the findings of the present study are consistent with those of previous researchers (Hirvela \& Pierson 2000) who concluded that L2 learners can improve their writing abilities with the help of self-assessment in writing classrooms. The findings of this study were also in line with those of Brindley \& Scoffield (1998); North (2000); and Oscarson(1989) who considered positive effects of self-assessment. This study was done in an EFL context. May be doing such research in an ESL context have different results. To this end, it is suggested that the study be done in an ESL context.

\section{References}

Bachman, Lyle \& Palmer, Adrian (1989).The construct validation of self-ratings of communicative language ability.Language Testing, 6, (1), 14-29.

Blanche, P. and Merino, B.J. (1989). Self-Assessment of Foreign-Language Skills: Implications for Teachers and Researchers, 39,3, 313-338.

Boud, David \& Falchikov, Nancy (2006).Aligning assessment with long-term learning. Assessment \& Evaluation in Higher Education, 31, (4), 399-413.

Brindley, C. \& Scoffield, S. (1998). Peer assessment in undergraduate programmes. Teaching in Higher Education, 3(1), 79-79.

Butler, Yuko Goto\& Lee, Jiyoon (2006). On-Task Versus Off-Task Self-Assessments Among Korean Elementary School Students Studying English. The Modern Language Journal, 90, (iv), 506-518.

Diltz, J. (2006). Words to voice: Three approaches for student self-evaluation. Teaching English in the TwoYear College, 34(1), 41-45.

Gardner, R.C., Tremblay, P., \&Masgoret, A. (1997). Towards a full model of second language learning: anempirical investigation. The Modern Language Journal, 81, 344-362.

Hirvela, A. \& Pierson, H. (2000). Portfolio: Vehicles for authentic self-assessment. In G. Ekbatani \& H. Pierson(Eds.), Learner- directed assessment in ESL (pp. 105-126). Manwah, N.J.: Lawrence Erlbaum Associates.

Horwitz, E. K. (2001). Language anxiety and achievement. Annual Review of Applied Linguistics, 21, 112-126.

Maclntyre, P. D., Noels, K. A., \& Clément, R. (1997). Biases in self-ratings of second language proficiency: The role of language anxiety. Language Learning, 47, 265-287.

Meihami1, H. and Varmaghani, Z. (2013). The Implementation of Self-Assessment in EFL Writing Classroom: An Experimental Study. International Letters of Social and Humanistic Sciences, 9, 39-48.

Mills, Nicole; Pajares, Frank \& Herron, Carol (2007). Self-efficacy of College Intermedidate French Students: Relation to Achievement and Motivation, Language Learning, 57, (3), 417-442.

Nielsen, K. (2014) Self-assessment methods in writing instruction: a conceptual framework, successful practices and essential strategies, Journal of research in Reading, 37,1, pp.1-16.

Noels, K.A., Pelletier, L.G., Cle'ment, R. and Vallerand, R.J. (2000) Why are you learning a second language? Motivational orientations and self-determination theory. Language Learning 50 (1), 57_85.

Oscarson, M. (1989). Self-assessment of language proficiency: Rationale and application. Language Testing, 6(1), 1-13.

Patri, M. (2002).The influence of peer feedback on self-and peer assessment of oral skills. Language Testing, 19 (2), 109-131.

Porter, C., and Cleland, J. (1995).The Portfolio as a Learning Strategy. Portsmouth, NH: Boynton/Cook Publishers,

Ross, Steven (1998). Self-assessment in second language testing: a meta analysis and analysis of experiential factors. Language Testing, 15, (1), 1-20.

Stefani, Lorraine, A. J. (1994). Peer, self and tutor assessment: Relative reliabilities. Studies in Higher Education, 19 (1), 1-7. Retreived March 3, 
Ushioda, E. (2001) Language learning at university: Exploring the role of motivational thinking. In Z.Do"rnyei and R. Schmidt (eds) Motivation and Second Language Acquisition (pp. 99_125). Honolulu, HI: University of Hawaii Press.

Warne, B.M. (2008). Writing steps: A recursive and individual experience. English Journal, 97(5), 23-27. 